\title{
Experience and Benefits of Using a Pre-drilled Screw Hole before Placing Anterior Cervical Plates in 330 Consecutive Patients during Anterior Cervical Discectomy and Fusion
}

\author{
KR Chin ${ }^{1,2,3}$, FJR Pencle ${ }^{4}$, AV Coombs ${ }^{4}$, L Lendvai ${ }^{4}$, JA Seale ${ }^{4}$, VB Cumming ${ }^{4}$, CA Bruce ${ }^{5}$
}

\begin{abstract}
Objective: The use of pre-drilled pilot holes to accurately place and fix anterior cervical plates $(A C P)$ is not established in the literature. Despite the usefulness of ACP after anterior cervical discectomy and fusion $(A C D F)$, there remain challenges to their precise placement and alignment, which could encroach and affect the adjacent level. Authors describe a technique of the precise placement of the shortest available ACP after one-level ACDF.

Methods: Technique description is given. Data were collected based on a retrospective review of 330 medical records from patients who underwent one-level ACDF with ACP fixation for various conditions. Patients who had ACP placed using the pre-drilled pilot hole technique were assigned to Group 1 and those who underwent traditional ACP fixation with the pilot holes drilled through the plates were assigned to Group 2. Lengths of ACP, heights of interbody cages and estimated blood loss were reviewed.

Results: Groups 1 included: 175 patients, Group 2 included: 155 patients. Mean age at surgery was 49.7 years (range 29-66 years) with no difference between groups $(p=0.85)$. There was no difference in gender distribution between groups ( $56 \%$ female), between body mass indices $(p=0.06)$, or smoking status reported $(p=0.45)$. We found that Group 1 utilized smaller plate sizes $(5-16 \mathrm{~mm})$ compared with Group $2(17-23 \mathrm{~mm})$. Mean cage sizes in Groups 1 and 2 were not different. Conclusions: A pre-drilled pilot hole technique for placement of ACP after ACDF offered a reliable way to safely secure the smallest plate available at surgery when compared with measuring a plate then placing the pilot hole through the plate.
\end{abstract}

Keywords: Anterior cervical plate, less exposure surgery, pilot hole, plate size, predrilled

\section{Experiencia y ventajas del uso de orificios pretaladrados para los tornillos antes de colocar las placas a 330 pacientes consecutivos durante una Discectomía y Fusión Cervical Anterior}

KR Chin ${ }^{1,2,3}$, FJR Pencle ${ }^{4}$, AV Coombs ${ }^{4}$, L Lendvai ${ }^{4}$, JA Seale $^{4}$, VB Cumming ${ }^{4}$, CA Bruce $^{5}$

\begin{abstract}
RESUMEN
Objetivo: El uso de orificios pretaladrados para colocar y fijar con precisión placas cervicales anteriores (PCA) no está establecido en la literatura. A pesar de la utilidad de la PCA después de una discectomía y fusión cervical anterior (DFCA), persisten los retos con respecto a su exacta colocación y alineación, que podrían interferir y afectar el nivel adyacente. Los autores describen una técnica de la colocación precisa de la PCA más corta disponible después de una DFCA de un nivel. Métodos: Se da la descripción de la técnica. Se recogieron datos sobre la base de una revisión
\end{abstract}

From: ${ }^{1}$ Charles E. Schmidt College of Medicine at Florida Atlantic University, USA, ${ }^{2}$ Herbert Wertheim College of Medicine at Florida International University, USA, ${ }^{3}$ Less Exposure Surgery Specialists Institute (LESS Institute), USA, ${ }^{4}$ Less Exposure Surgery (LES) Society, USA and ${ }^{5}$ Department of Surgery, Radiology, Anaesthesia and Intensive Care, The University of the West Indies,
Mona, Jamaica WI.

Correspondence: Dr K Chin, Less Exposure Surgery Specialists Institute (LESS Institute), $1100 \mathrm{~W}$. Oakland Park Blvd. Suite \#3, Fort Lauderdale, FL, 33311, USA. Email: kingsleychin@thelessinstitute. com 
retrospectiva de 330 historias clínicas de pacientes a quienes se les practicó una DFCA de un nivel con fijación de la PCA a causa de diferentes condiciones. Los pacientes a los que se le había colocado una PCA mediante la técnica de orificios pilotos pretaladrados, fueron asignados al Grupo 1, en tanto que aquellos a quienes se les practicó fijación tradicional de PCA con los orificios pilotos taladrados a través de las placas, fueron asignados al grupo 2. Se analizaron las longitudes de las PCA, las alturas de los cajetines intervertebrales, y la pérdida de sangre estimada.

Resultados: El Grupo 1 comprendió 175 pacientes; el Grupo 2 comprendió 155 pacientes. La edad promedio al momento de la cirugía fue de 49.7 años (rango: 29 a 66 años), sin diferencias entre grupos $(\mathrm{p}=0.85)$. No hubo diferencias en la distribución de género entre los grupos (56\% mujeres), $n i$ entre los índices de masa corporal $(\mathrm{p}=0.06)$, o los reportes de la condición de fumador $(\mathrm{p}=0.45)$. Encontramos que el Grupo 1 utilizó tamaños de placa más pequeños (5 a 16 mm) en comparación con el Grupo 2 (17 a $23 \mathrm{~mm})$. Las dimensiones de los cajetines intervertebrales de los grupos 1 y 2 no fueron diferentes.

Conclusiones: La técnica de orificio piloto para colocar las PCA después de una DFCA ofreció una manera confiable para fijar con seguridad la placa más pequeña disponible en la cirugía, en comparación con medir una placa, y hacer luego el orificio piloto a través de la placa.

Palabras claves: placa cervical anterior, cirugía de menos exposición, orificio, tamaño de la placa, pretaladrado

West Indian Med J 2017; 66 (3): 446

\section{INTRODUCTION}

Anterior cervical plating has proven useful after anterior cervical decompression and fusion (ACDF) promoting fusion and resulting in very good clinical outcomes, especially in multi-level procedures (1-7). An improved fusion rate is a significant advantage of using anterior cervical plates (ACP) as an adjunct to fusion with a cage. Other advantages include, decreased incidence of cage subsidence and local kyphosis, early ambulation and decreased need for postoperative rigid orthoses $(8,9)$. Despite the usefulness of ACP after ACDF, there remains challenges to their precise placement and alignment in situ (10-13) and when placed within $5 \mathrm{~mm}$ of the adjacent level has been shown to cause ossification (14). The use of pre-drilled pilot holes facilitating pedicle screw placement has been tested with positive results (15-17); however, we found only one reference to the use of pre-drilled pilot holes to assist with ACP placement (18).

We have focussed on reporting the technique for the placement of a pre-drilled pilot hole at the anterior inferior corner of the vertebra partially through the endplate that facilitated the placement of the shortest available ACP to avoid the adjacent level and allow for less exposure surgery (LES). Also included, are preliminary results, retrospectively comparing consecutive patients, in which the traditional technique of drilling holes through the cervical plate was used, with patients in whom we adopted the technique of using a pre-drilled pilot hole before placing the cervical plate.

\section{SUBJECTS AND METHODS}

The medical records of 330 patients, who presented with cervical degenerative disc disease (DDD) resulting in myelopathy with or without radiculopathy, were reviewed. Indications for ACDF included cervical spondylosis, herniated discs (Figs. $1 \mathrm{~A} / \mathrm{B})$, degenerative disc disease with instability and facet arthritis, tropism or facetogenic pain.

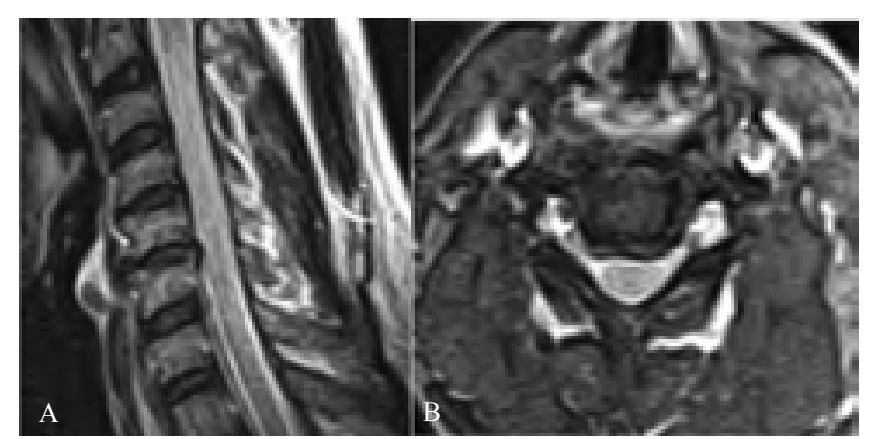

Fig. 1: A) Sagittal view in an example pre-operative magnetic resonance imaging demonstrating C5-6 left paracentral herniated nucleus pulposus for which conservative treatment failed. B) Axial view, in same example, preoperative magnetic resonance imaging as in $4 \mathrm{~A}$.

Patients who had ACP placed using the pre-drilled pilot hole technique were assigned to Group 1 and those who underwent traditional ACP fixation were assigned to Group 2. Lengths of ACP, heights of interbody cages and estimated blood loss (EBL) were reviewed. The following description illustrates the use of the pre-drilled pilot hole technique in placing the smallest available plate during one-level ACDF.

\section{Less exposure surgery technique}

Signed consent was obtained for the procedure which was under general anaesthesia; patients were prepped and draped under sterile conditions. A modified approach to the standard Smith-Robinson operative technique was used (19). Surgical exposure of the desired vertebral level was achieved through a transverse midline anterior cervical incision. Following discectomy with pituitary ronguers, curette and burr drill to remove affected disc, the posterior longitudinal ligament was 
retained in situ (20).

The approximately sized polyetheretherketone (PEEK) cage was chosen using a trial in accordance with the patient's anatomy and delicately inserted. A drill was then used to prepare a hole on the left side of the inferior endplate of the superior vertebral body (Fig. 2).

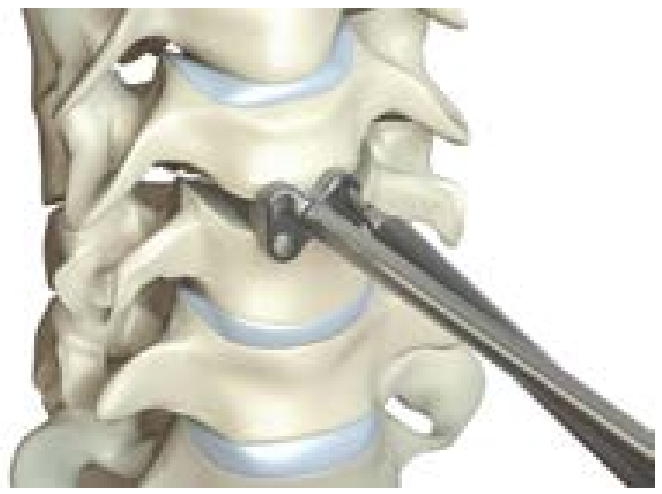

Fig. 2: Illustration demonstrating pilot hole creation using trial guide and drill.

Lateral fluoroscopic views were done to determine the optimal trajectory. We drilled aiming towards the posterior aspect of the superior endplate of the vertebral body. The smallest cervical plate available was then placed along with an appropriately fitted screw to fix the plate in position. This allowed the plate the capability to rotate/move side-to-side for proper mediolateral alignment without cephalad creep. The plate was then straightened and the remaining three screws were placed through the plate with the desired trajectory (Figs. 3A/ B). All screws were placed by a single surgeon.

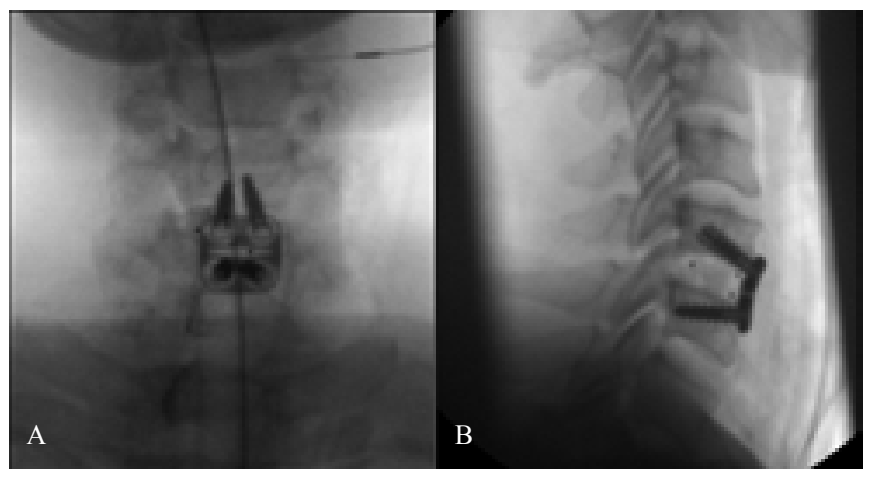

Fig. 3: A) Anteroposterior fluoroscopic view of anterior cervical plates plus four screws in situ. B) Lateral fluoroscopic image of anterior cervical plates in situ in C5-6 after anterior cervical discectomy and fusion.

\section{Statistical analysis}

Values are expressed as counts or means. Intergroup comparisons were made using $t$-test. Data were analysed using the Stata statistical software version 12 (Statacorp, TX, USA). Tests were considered significant if $p<0.05$.

\section{RESULTS}

Groups 1 and 2 included: 165 cases each. The mean age at the time of surgery was 50.2 years in Group 1 (range 37 to 62 years) and 49.4 years in Group 2 (range 29 to 66) and the mean ages of the two groups were not significantly different $(p=$ 0.85 ). The total patient population was $56 \%$ female, without significant differences in gender distribution between groups. There were no significant differences between the two groups' body mass indices $(p=0.06)$ or smoking status reported $(p=$ 0.45 ). We found that Group 1 utilized smaller plate sizes (5$16 \mathrm{~mm}$ ) compared with Group $2(17-23 \mathrm{~mm})$. Mean cage size in Groups 1 and 2 was not different. Mean EBL at surgery for Group 1 was $57.7 \mathrm{~mL}$ and Group 2 was $105.75 \mathrm{~mL}$. All cases had postoperative radiographs done at two weeks, and were considered satisfactory by a board certified radiologist, the operating surgeon and independent observers (Figs. 4A/B).

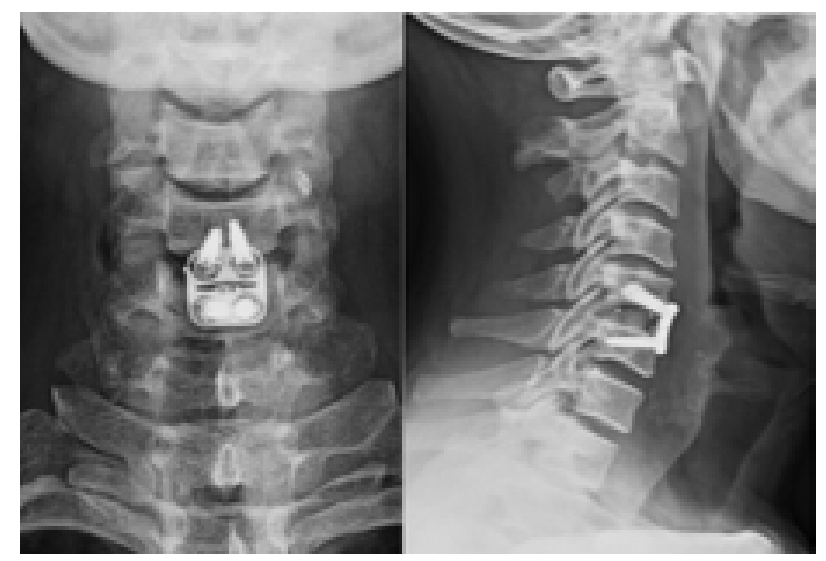

Fig. 4: A) Anteroposterior radiograph showing anterior cervical plates securely placed at two weeks postoperatively. B) Lateral radiograph at two weeks postoperatively.

\section{DISCUSSION}

Anterior cervical plating in single level ACDF has been shown to be a safe procedure with no significant increase in complications (21). Moreover, plate size and length may impact the incidence of adjacent segment ossification, thus using the smallest ACP is desirable (22). The challenge with applying the traditional technique of ACP placement with smaller sized plates is that, the smaller the plate, the easier it is to lose its accurate position on the spine either through sudden slippage or gradual shifting during the drilling process. Additionally, if an optimum sized plate is not placed with meticulous attention to technique and appropriate screw lengths, catastrophic complications, although rare, may arise from fractures and intra-disc screw placement to oesophageal compression and airway compromise (23).

The description of a pre-drilled pilot hole, as illustrated, allowed the surgeon to accurately predetermine screw placement. This technique also allowed delicate entry through the anterior-inferior corner of the endplate, halfway inside the disc space; which would be difficult if attempted through the screw-hole with a drill guide. It was technically more difficult to control the plate from creeping when placing a hole through the plate than placing a screw through a pre-drilled pilot 
hole. Placing a pre-drilled pilot hole also gave the surgeon greater visualization of the chosen position for the optimal screw placement and trajectory. Our preliminary data revealed that the use of the pre-drilled pilot hole technique consistently allowed the surgeon to utilize the smallest plates available.

Another important advantage of using a pre-drilled pilot hole to facilitate the placement of shorter ACP is that there is much more room between the tips of the plates and either endplate. This minimizes the risk of developing adjacent segment disease (ASD), which occurs with higher frequency with longer plates $(14,24,25)$. In fact, Park et al concluded that a decreased incidence in ASD was observed when at least 5 $\mathrm{mm}$ between plate margin and adjacent disc space is ensured (14). Limitations of this study include a retrospective review. Further comparative study between the two techniques, including radiological measurements to objectively assess any statistically significant difference in endplate encroachment is required.

It is worth noting that the shorter plates used in Group 1 had new design features compared to traditional plates. These features include; shorter overall length (Fig. 5A) and steep variable rostrocaudal screw angulation (Fig. 5B).

The screw has a 14-degree cone (7 in each direction) and performs clinically to a much higher degree of angulation (30 to 40 degree cone).

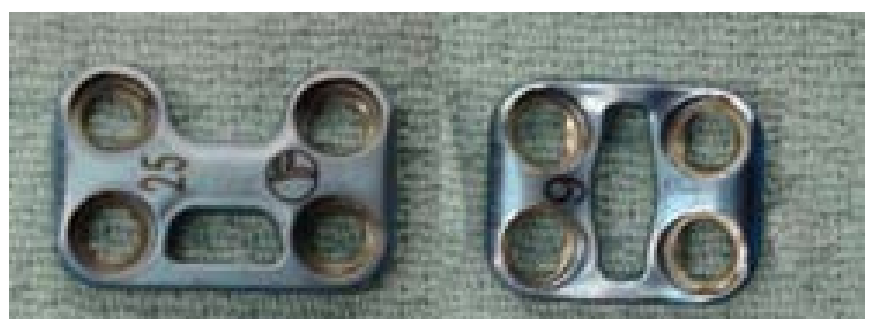

A

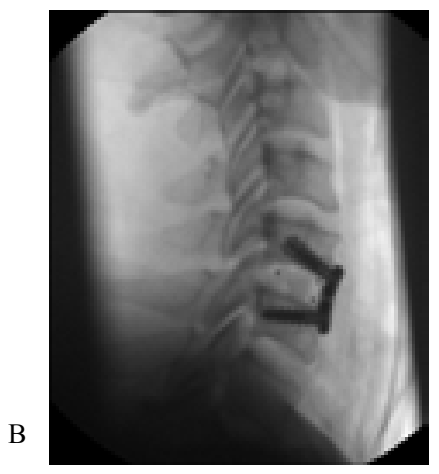

Fig. 5: A) Photograph comparing longer plate next to a new shorter plate. B) Photographic depiction of angulated $4 \times 4.2 \times 14 \mathrm{~mm}$ screws in a $7 \mathrm{~mm}$ anterior cervical plates.

\section{CONCLUSION}

Using a pre-drilled pilot hole technique for ACP placement after ACDF offers a reliable way to safely secure the smallest plate available to the surgeon, which also avoids adjacent endplate encroachment compared with traditional techniques of drilling solely through the plate holes.

\section{AUTHORS' NOTE}

Conflicts of interest and sources of funding: We did not seek or receive any funding from the National Institutes of Health (NIH), Wellcome Trust, Howard Hughes Medical Institute (HHMI), or others for this work. Dr KR Chin is a shareholder in and receives other benefits from SpineFrontier Inc, neither of the other two authors (FJRP, AVC, LL, JAS, VC) have any potential conflicts of interest to declare for this work.

\section{REFERENCES}

1. Daffner SD, Wang JC. Anterior cervical fusion: the role of anterior plating. Instr Course Lect 2009; 58: 689-98.

2. Mobbs RJ, Rao P, Chandran NK. Anterior cervical discectomy and fusion: analysis of surgical outcome with and without plating. J Clin Neurosci 2007; 14: 639-42.

3. Gonugunta V, Krishnaney AA, Benzel EC. Anterior cervical plating. Neurol India 2005; 53: 424-32.

4. Song KJ, Kim GH, Choi BY. Efficacy of PEEK cages and plate augmentation in three-level anterior cervical fusion of elderly patients. Clin Orthop Surg 2011; 3: 9-15.

5. Wang JC, McDonough PW, Endow KK, Delamarter RB. Increased fusion rates with cervical plating for two-level anterior cervical discectomy and fusion. Spine (Phila Pa 1976) 2000; 25: 41-5.

6. Wright IP, Eisenstein SM. Anterior cervical discectomy and fusion without instrumentation. Spine (Phila Pa 1976) 2007; 32: 772-4.

7. Chin KR, Ricchetti ET, Yu WD, Riew KD. Less exposure surgery for multilevel anterior cervical fusion using 2 transverse incisions. J Neurosurg Spine 2012; 17: 194-8.

8. Moftakhar R, Trost GR. Anterior cervical plates: a historical perspective. Neurosurg Focus 2004; 16: E8.

9. Song KJ, Taghavi CE, Hsu MS, Lee KB, Kim GH, Song JH. Plate augmentation in anterior cervical discectomy and fusion with cage for degenerative cervical spinal disorders. Eur Spine J 2010; 19: 1677-83.

10. Chin KR, Stieber JR, Mehta S, Cohen JD, Auerbach JD. The manubrium as an external guide for centralizing anterior cervical plates: technique tips and initial experience. Spine (Phila Pa 1976) 2010; 35: E244-7.

11. Ipsen BJ, Kim DH, Jenis LG, Tromanhauser SG, Banco RJ. Effect of plate position on clinical outcome after anterior cervical spine surgery. Spine J 2007; 7: 637-42.

12. Park Y, Maeda T, Cho W, Riew KD. Comparison of anterior cervical fusion after two-level discectomy or single-level corpectomy: sagittal alignment, cervical lordosis, graft collapse, and adjacent-level ossifica-tion. Spine J 2010; 10: 193-9.

13. Auerbach JD, Weidner Z, Pill SG, Mehta S, Chin KR. The mandibular angle as a landmark for identification of cervical spinal level. Spine (Phila Pa 1976) 2009; 34: 1006-11.

14. Park JB, Watthanaaphisit T, Riew KD. Timing of development of adja-cent-level ossification after anterior cervical arthrodesis with plates. Spine J 2007; 7: 633-6.

15. Zheng $\mathrm{X}$, Chaudhari R, Wu C, Mehbod AA, Transfeldt EE. Subaxial cervical pedicle screw insertion with newly defined entry point and tra-jectory: accuracy evaluation in cadavers. Eur Spine J 2010; 19: 105-12.

16. Chen LH, Tai CL, Lai PL, Lee DM, Tsai TT, Fu TS et al. Pullout strength for cannulated pedicle screws with bone cement augmentation in severely osteoporotic bone: influences of radial hole and pilot hole tap-ping. Clin Biomech 2009; 24: 613-8.

17. Ryken TC, Owen BD, Christensen GE, Reinhardt JM. Image-based drill templates for cervical pedicle screw placement. J Neurosurg Spine 2009; 10: 21-6.

18. Park JY, Zhang HY, Oh MC. New technical tip for anterior cervical plating: make hole first and choose the proper plate size later. J Korean Neurosurg Soc 2011; 49: 212-6.

19. Robinson RA, Smith GW. Anterolateral cervical disc removal and inter-body fusion for cervical disc syndrome. Bull John Hopkins Hosp 1955; 96 SRC - GoogleScholar: 223-4. 
20. Chin KR, Ghiselli G, Cumming V, Furey CG, Yoo JU, Emery SE Postoperative magnetic resonance imaging assessment for potential compressive effects of retained posterior longitudinal ligament after anterior cervical fusions: a cross-sectional study. Spine 2013; 38: 253-6.

21. Isomi T, Panjabi MM, Wang JL, Vaccaro AR, Garfin SR, Patel T. Stabilizing potential of anterior cervical plates in multilevel corpectomies. Spine 1999; 24: 2219-23.

22. Park JB, Cho YS, Riew KD. Development of adjacent-level ossification in patients with an anterior cervical plate. J Bone Joint Surg Am 2005; 87: $558-63$.
23. Rhee JM, Park JB, Yang JY, Riew DK. Indications and techniques for anterior cervical plating. Neurol India 2005; 53: 433-9.

24. Koller H, Hempfing A, Ferraris L, Maier O, Hitzl W, Metz-Stavenhagen P. 4- and 5-level anterior fusions of the cervical spine: review of literature and clinical results. Eur Spine J 2007; 16: 2055-71.

25. Goffin J, van Loon J, Van Calenbergh F, Plets C. Long-term results after anterior cervical fusion and osteosynthetic stabilization for fractures and/or dislocations of the cervical spine. J Spinal Disord 1995; 8: 500-8. 